\title{
Growth of Bali bulls on rations containing Sesbania grandiflora in central Lombok, Indonesia
}

\author{
DAHLANUDDIN $^{1}$, BAIQ TUTIK YULIANA ${ }^{2}$, TANDA PANJAITAN ${ }^{2}$, MICHAEL J. HALLIDAY $^{3}$ AND H. MAX \\ SHELTON $^{3}$ \\ ${ }^{I}$ Faculty of Animal Science, University of Mataram, Lombok, Indonesia. www.unram.ac.id/en/ \\ ${ }^{2}$ Assessment Institute for Agricultural Technology, Lombok, Indonesia. \\ ${ }^{3}$ School of Agriculture and Food Sciences, The University of Queensland, St Lucia, Qld, Australia. \\ www.uq.edu.au/agriculture/
}

Keywords: Bali cattle, growth rate, agroforestry, fodder trees.

\section{Introduction}

The demand for meat in Indonesia is currently growing by up to $8 \%$ per year, with beef cattle fattening identified as a major livestock industry (Purwantara et al. 2012). Bali cattle (Bos javanicus) account for almost $27 \%$ of total beef cattle in Indonesia; they are the predominant breed in the eastern islands and are highly favored by smallholder farmers for their high fertility, low calf mortality and generally higher price at markets (Purwantara et al. 2012). Lombok in west Nusa Tenggara is one of the biggest suppliers of Bali cattle in Indonesia.

A major constraint to improving the overall productivity of Bali cattle is their slow growth rate, due to lack of readily available, inexpensive, high-quality protein sources. Fodder tree legumes, such as sesbania (Sesbania grandiflora), offer a fast-growing, low-cost source of protein (Evans and Rotar 1987). Farmers in Lombok have established a unique and productive integrated farming system by planting sesbania trees along the bunds of rice paddies, providing forage and timber without significantly compromising rice yield (Dahlanuddin and Shelton 2005).

As only the central part of Lombok is intensively planted with sesbania, a collaborative project funded by

Correspondence: Dahlanuddin, Faculty of Animal Science, University of Mataram, Jalan Majapahit, Mataram, Mataram City, West Nusa Tenggara 83125, Indonesia.

Email: dahlan travel@yahoo.com the Australian Centre for International Agricultural Research (ACIAR) is underway aiming to: (a) characterize the existing cattle fattening systems; and (b) assess the impact of differing levels of sesbania feeding on the growth rate of Bali bulls from weaning to maturity (about 30 months old).

\section{Materials and Methods}

Objective 1 - Pre-trial

Three typical cattle fattening groups were selected in central Lombok in the hamlets of Montong Oboq, Bun Prie and Repok Nyerot. Commencing March 2012, animal weights, feed regimes and sale prices were monitored regularly to understand the fattening profiles of the 3 groups.

\section{Objective 2 - Feeding trial}

Within each of these groups, a semi-controlled feeding trial was begun in July 2012, using 20 male Bali calves with an average age of $7.6 \pm 0.4$ months and mean live weight (LW) of $90 \pm 5.8 \mathrm{~kg}$. Bulls were randomly allocated to the 3 villages in August 2012. Farmers were requested to feed sesbania to these bulls at rates up to $20 \%$ (fresh weight) of total diet in Montong Oboq, $40 \%$ in Bun Prie and $60 \%$ in Repok Nyerot. A rice bran supplement of $0.5 \mathrm{~kg}$ fresh weight $/ 100 \mathrm{~kg} \mathrm{LW}$ was supplied for farmers at Bun Prie and Repok Nyerot, where higher levels of sesbania were being fed. The actual amounts and proportions of different feeds offered were recorded on 6 consecutive days in March 2013. Live weight was measured monthly. 


\section{Results and Discussion}

The pre-trial profiles of the 3 groups are presented in Table 1. Farmers in Repok Nyerot achieved the highest daily gains and sale weights, but the monthly profit margin was slightly lower than for those in Montong
Oboq. The higher gains were thought to be due to higher levels of sesbania feeding. This aspect was tested in the subsequent feeding trial. Montong Oboq had the longest fattening period (12.5 \pm 1.3 months), as they started with the lightest bulls $(119 \pm 15 \mathrm{~kg})$.

Table 1. Pre-trial profiles of groups fattening Bali cattle at 3 sites in central Lombok (March-July 2012).

\begin{tabular}{lccc}
\hline Categories & Montong Oboq & Bun Prie & Repok Nyerot \\
\hline No of farmers & 30 & 19 & 30 \\
No of cattle/household/period & 1 & $1-2$ & $2-3$ \\
No of cattle monitored & 8 & 30 & 23 \\
Initial live weight $(\mathrm{kg})$ & $119 \pm 15$ & $195 \pm 5$ & $188 \pm 13$ \\
Sale weight $(\mathrm{kg})$ & $268 \pm 3$ & $237 \pm 6$ & $312 \pm 11$ \\
Fattening period (months) & $12.5 \pm 1.3$ & $4.8 \pm 0.4$ & $8.3 \pm 0.9$ \\
Average daily gain $(\mathrm{kg} / \mathrm{hd} / \mathrm{d})$ & $0.44 \pm 0.13$ & $0.32 \pm 0.03$ & $0.58 \pm 0.05$ \\
Animal value at start $(\mathrm{Rp} \mathrm{x10} / \mathrm{kg})$ & $3.3 \pm 1.4$ & $3.0 \pm 0.1$ & $3.3 \pm 0.3$ \\
Animal value at sale $(\mathrm{Rp} \mathrm{x10} / \mathrm{kg})$ & $2.3 \pm 0.2$ & $3.0 \pm 0.1$ & $3.0 \pm 0.1$ \\
Margin $(\mathrm{Rp} / \mathrm{head} / \mathrm{month})$ & $49.9 \pm 4.3$ & $29.9 \pm 3.1$ & $47.1 \pm 5.3$ \\
\hline
\end{tabular}

In the feeding trial, farmers could not achieve the recommended levels of sesbania feeding (Table 2).

Table 2. Growth rates of Bali bulls fed sesbania foliage at 3 sites in central Lombok (August 2012-March 2013).

\begin{tabular}{lccc}
\hline Variables & Montong Oboq & Bun Prie & Repok Nyerot \\
\hline Land ownership (ha) & $0.39 \pm 0.15$ & $0.23 \pm 0.01$ & $0.53 \pm 0.08$ \\
No of farmers selected for trial & 6 & 6 & 8 \\
No of sesbania trees/farmer & $199 \pm 37$ & $321 \pm 79$ & $326 \pm 31$ \\
No of bulls allocated to village & 6 & 6 & 8 \\
Starting weight of bulls (kg) & $87 \pm 3$ & $93 \pm 2$ & $89 \pm 1$ \\
Requested level of sesbania in diet (\% fresh) & 20 & 40 & 60 \\
Actual proportion of sesbania in diet (\% fresh) & $29 \pm 6$ & $49 \pm 2$ & $45 \pm 4$ \\
Amount of rice bran offered (kg DM/hd/d) & 0 & $0.9 \pm 0.1$ & $1.2 \pm 0.1$ \\
Average daily gain (kg/hd/d) & $0.35 \pm 0.02$ & $0.34 \pm 0.02$ & $0.50 \pm 0.04$ \\
\hline
\end{tabular}

Despite similar proportions of sesbania in the diet, daily gains were higher at Repok Nyerot $(0.50 \mathrm{~kg} / \mathrm{hd} / \mathrm{d})$ than at Bun Prie $(0.34 \mathrm{~kg} / \mathrm{hd} / \mathrm{d})$; gains at Montong Oboq were $0.35 \mathrm{~kg} / \mathrm{hd} / \mathrm{d}$, where sesbania feeding was least and rice bran was not fed. Differences in growth rates may have been related to variation in feeding practices by individual farmers, i.e., total dry matter offered/day and differing quality of the grass offered.

These data offer a basic understanding of sesbania feeding systems in Indonesia and their productivity. Growth rates were comparable with previously record- ed data, namely $0.38 \mathrm{~kg} / \mathrm{d}$ for bull calves of similar age fed $30 \%$ sesbania; however, they were much higher than $0.2 \mathrm{~kg} / \mathrm{d}$ achieved in traditional fattening systems comprising diets of predominantly local grass species (Dahlanuddin et al. 2013).

\section{Conclusion}

Although some difficulties occurred with this on-farm research, the study suggests that the inclusion of sesbania in the fattening diet can boost animal growth 
rates. The trial will continue to monitor the growth path on-farm until the bulls reach maturity.

\section{Acknowledgments}

This study was funded by ACIAR.

\section{References}

Evans DO; Rotar PP. 1987. Productivity of sesbania species.

Tropical Agriculture 64:193-200.
Dahlanuddin H; Shelton M. 2005. Sesbania grandiflora: a successful tree legume in Lombok, Indonesia. Tropical Grasslands 39:217.

Dahlanuddin H; Yulianto TB; Priyanti A; Poppi DP; Quigley SP. 2013. Weaning and Supplementation Increase Liveweight Gain of Bali (Bos javanicus) Cattle of Smallholder Farmers in Central Lombok, Indonesia. Journal of Animal Production (in press).

Purwantara B; Noor RR; Andersson G; Rodriguez-Martinez H. 2012. Banteng and Bali Cattle in Indonesia: Status and Forecasts. Reproduction in Domestic Animals 47:2-6.

\section{(c) (i) (5) (2)}

Tropical Grasslands-Forrajes Tropicales is an open-access journal published by Centro Internacional de Agricultura Tropical (CIAT). This work is licensed under a Creative Commons Attribution-NonCommercial-ShareAlike 3.0 Unported License. To view a copy of this license, visit http://creativecommons.org/licenses/by-nc-sa/3.0/. 
Dahlanuddin; Yuliana BT; Panjaitan T; Halliday MJ; Shelton HM. 2013. Growth of Bali bulls on rations containing Sesbania grandiflora in central Lombok, Indonesia. Tropical Grasslands - Forrajes Tropicales $1: 63-65$.

DOI: $\underline{10.17138 / T G F T(1) 63-65}$

This paper was presented at the $22^{\text {nd }}$ International Grassland Congress, Sydney, Australia, 15-19 September 2013. Its publication in Tropical Grasslands - Forrajes Tropicales is the result of a co-publication agreement with the IGC 2013 Organizing Committee. Except for adjustments to the journal's style and format, the text is essentially the same as that published in: Michalk LD; Millar GD; Badgery WB; Broadfoot KM, eds. 2013. Revitalising Grasslands to Sustain our Communities. Proceedings of the $\mathbf{2 2}^{\text {nd }}$ International Grassland Congress, Sydney, Australia, 2013. New South Wales Department of Primary Industries, Orange, NSW, Australia. p. $264-265$. 